\title{
INTERACTIVE METHODS OF TEACHING FOREIGN LANGUAGES IN HIGHER EDUCATION INSTITUTIONS
}

\section{MÉTODOS INTERATIVOS DE ENSINO DE LÍNGUAS ESTRANGEIRAS EM INSTITUIÇÕES DE ENSINO SUPERIOR}

\section{MÉTODOS INTERACTIVOS DE ENSEÑANZA DE LENGUAS EXTRANJERAS EN INSTITUCIONES DE EDUCACIÓN SUPERIOR}

\author{
Oleksiienko A. Larysa ${ }^{1}$ \\ Trubitsyna M. Olga² \\ Balanaieva V. Oksana ${ }^{3}$ \\ Mamonova I. Olena ${ }^{4}$ \\ Polytsia D. Tetiana ${ }^{5}$
}

\begin{abstract}
This study investigates how family lineage descent groups influence the intergenerational transmission of education for the cohorts of 1940-1989 in the Democratic Republic of Congo (DRC). The study applies both transition matrix and intergenerational persistence (IGP) methods, using the father's years of schooling as a proxy for parental education. The findings suggest a pronounced steady persistence in education for the estimated mean regression coefficient over a period of 49 years. Moreover, results by gender indicate that intergenerational persistence in education has significantly decreased for males in recent cohorts but slightly increased for females. Furthermore, findings suggest that intergenerational persistence has been decreasing in matrilineal descent groups in recent cohorts, while increasing for the patrilineal descent groups. The study gives a good sense of the relationship between family lineage descent and intergenerational transmission of education in DRC. In addition, it indicates that there is both substantial upward and downward intergenerational education mobility in the country.
\end{abstract}

\footnotetext{
${ }^{1}$ Alfred Nobel University. Dnipro, Dnipropetrovsk Oblast, Ukraine.

2 South-Ukrainian National Pedagogical University. Odesa, Odessa Oblast, Ukraine.

${ }^{3}$ Donetsk Law Institute of the Ministry of Internal Affairs of Ukraine. Kryvyi Rih, Dnipropetrovsk Oblast, Ukraine.

${ }^{4}$ Donetsk Law Institute of the Ministry of Internal Affairs of Ukraine. Kryvyi Rih, Dnipropetrovsk Oblast, Ukraine.

${ }^{5}$ National Pirogov Memorial Medical University. Vinnytsia, Vinnytsia Oblast, Ukraine.
} 
Keywords: Interactive teaching methods, technology-enhanced language learning, Mobile learning, Mulmedia language learning, Socialized language learning, Gamified language learning.

Resumo: Nos últimos dez anos, o número de estudos sobre a eficácia das tecnologias e métodos interativos de ensino de línguas estrangeiras está em constante crescimento. Essa tendência se deve à disseminação da tecnologia no processo educacional e à necessidade dos alunos em utilizá-la devido à necessidade de adquirir habilidades de comunicação e conhecimento profissional de línguas estrangeiras. Todos os itens acima requerem o estudo das tendências modernas. A utilização de métodos interativos de ensino de línguas estrangeiras e a eficácia de métodos de ensino interativos é uma questão muito relevante. Este artigo sistematiza os tipos e efeitos das tecnologias interativas de ensino de línguas estrangeiras em instituições de ensino superior tendo como base um estudo de 76 publicações em 2010 -2020. Verificou-se que 63\% dos estudos revelaram efeitos positivos do uso de tecnologias interativas. O maior efeito dos métodos interativos de ensino de línguas estrangeiras é observado na aprendizagem de palavras, aprendizagem integrada, leitura e fala. O artigo comprova o crescimento do nível de uso e do papel das tecnologias interativas para simplificar e facilitar as tarefas mais simples do processo educacional: tradução, pronúncia, interação. A abordagem didática para o ensino de línguas estrangeiras está mudando para uma diferenciada. O estudo mostrou que os efeitos positivos dos métodos interativos podem desaparecer com o tempo, à medida que os alunos perdem o interesse em uma nova tecnologia interativa que se torna uma ferramenta de aprendizagem. Para resolver este problema, os professores podem usar diferentes formas de estratégias inovadoras e habilidades de ensino. Eles podem integrá-los ao aprendizado usando a tecnologia.

Palabras-clave: Métodos de enseñanza interactivos, aprendizaje de idiomas mejorado por la tecnología, aprendizaje móvil, aprendizaje de idiomas mulmedia, aprendizaje de idiomas socializado, aprendizaje de idiomas gamificado.

Resumen: Este estudio investiga cómo los grupos de ascendencia de linaje familiar influyen en la transmisión intergeneracional de la educación para las cohortes de 1940-1989 en la República Democrática del Congo (RDC). El estudio aplica tanto la matriz de transición como los métodos de persistencia intergeneracional (IGP), utilizando los años de escolaridad del padre como un indicador de la educación de los padres. Los hallazgos sugieren una persistencia constante y pronunciada en la educación para el coeficiente de regresión medio estimado durante un período de 49 años. Además, los resultados por género indican que la persistencia intergeneracional en la educación ha disminuido significativamente para los hombres en las cohortes recientes, pero ha aumentado ligeramente para las mujeres. Además, los hallazgos sugieren que la persistencia intergeneracional ha disminuido en los grupos de descendencia matrilineal en las cohortes recientes, mientras que ha aumentado en los grupos de descendencia patrilineal. El estudio da una buena idea de la relación entre el linaje familiar y la transmisión intergeneracional de la educación en la República Democrática del Congo. Además, indica que existe una considerable movilidad educativa intergeneracional ascendente y descendente en el país.

Palabras clave: Métodos de enseñanza interactivos, aprendizaje de idiomas mejorado por la tecnología, aprendizaje móvil, aprendizaje de idiomas mulmedia, aprendizaje de idiomas socializado, aprendizaje de idiomas gamificado. 


\section{INTRODUCTION}

Interactive teaching methods contribute to the formation of flexible forms, formats and teaching methods (Stewart, C., Wolodko, B., 2016; Zhu, E., 2017; Rolim, C. and Isaias, P., 2019). As a result, the level of productivity and self-efficacy of students and teachers increases due to the intensification of the educational process (Benta, D., Bologa, G., Dzitac I., 2015; Moreno, V., et al, 2016). Interactive teaching methods allow to adapt the educational process and learning to the requirements of the main participants (Arrosagaray, M., et al, 2019), to improve the level of communication between participants (Keane, T., Keane, W. F., Blicblau, A. S., 2016).

Interactivity is considered as an interaction between individuals and systems for information exchange (Georgieva-Tsaneva, G., Bogdanova, G., Negoslav Subev, N., 2017) using "real-time applications" (Kebble, PG, 2017). So, interactive methods can be considered as ways of interaction. The integration of interactive technologies into learning provides the introduction of a systematic dynamic approach (Serrano, D. R., et al, 2019) into the learning process, "increased focus on student success" (Drake, B. M., Walz, A., 2018).

The Institute for the Future, a nonprofit research group, identifies six future trends that will determine global change: "increased lifespans, smart machines, big data, new media ecology, online networks, and increased global interconnectivity" (Institute for the Future, 2017). These trends will require new skills from students and teachers, which will require new teaching methods and learning priorities. Due to the progress of the integration of machine translation and artificial intelligence, many simple tasks in foreign language learning will be replaced by automation.

The aim of the article is to conceptualize interactive methods of teaching foreign languages in higher education institutions.

The main issues of the study are:

1. Historical trends in the usage of interactive methods of teaching foreign languages.

2. Types of interactive methods of teaching foreign languages in higher education institutions.

3. The effectiveness and effects of the introduction of interactive methods of teaching foreign languages in higher education institutions.

\section{LITERATURE REVIEW}

The effectiveness of interactive technologies in teaching foreign languages in higher education institutions has been proven in a number of studies. Recent works confirm the following positive changes: «increase of selfawareness, improvement of social and communicative skills; ... Benefits of communication in small groups: comparing life experiences, broadening of outlook, active involvement of people with special needs, ability to relieve psychological tension, communicative skills improvement, ability to teach each other; ... Better understanding of different processes that occur in public life; understanding of the culture of different ethnic groups; better understanding of English; the ability to use modern ICT in everyday life "(Viktorov, LV, Kocharyan, $A B, \&$ Korotun, OO, 2018). 
Learning foreign languages is transformed in the direction of providing flexibility, inclusion, personalization of the educational process (Pokrivcakova, S., 2019). The use of interactive technologies led to the development of the concept of ICALL - intelligent computer-assistant language learning. Interactive tools are implemented in "personalized learning materials, machine translation tools, Al writing assistants, chatbots, Al-powered language learning software-platforms and apps, intelligent tutoring systems, adaptive and intelligent systems for collaborative learning support, intelligent virtual reality" (Pokrivcakova, S., 2019).

Due to the integration of technologies into learning, there is a gradual conceptualization of linguistic and cultural aspects of learning through technological solutions from the beginning of the usage of local networks of computers to advanced technologies (virtual reality and augmented reality) (Blyth, C., 2018).

English language teachers are positive about the usage of technology in foreign language teaching, understanding the importance of technology and its usage. However, the simplest technologies of interaction are usually used: sending e-mails and presentations. Foreign language programs should include computer integration courses (Zekiye, Ö. Z. E. R., 2018). Most students and teachers enjoy using interactive technologies in foreign language teaching, despite the shortcomings (Trigueros Rueda, Y., 2017). This ensures the implementation of a diversified approach to foreign language teaching.

The main types of foreign language learning technologies are "technologies for mobile learning, multimedia learning and socialization, speech-to-text and text-to-speech recognition, and digital-game-based learning". The main tasks of using technology are the development of practical skills, providing students with educational content, improving interaction, changing approaches to learning (Zhang, R., \& Zou, D., 2020).

\section{DATA AND METHODS}

\section{Data}

Publications have been classified by the following main areas, research issues in order to understand the trends in the integration of interactive methods of teaching foreign languages in the educational process in universities over the past ten years: research methodology, types of interactive technologies in foreign languages, effectiveness of interactive technologies in foreign languages. 
Table 1. Distribution of scientific publications concerning the study of interactive methods of teaching foreign languages in higher education institutions published from 2010 to 2020 in the 10 selected journals

\begin{tabular}{|c|c|c|c|c|}
\hline Journal & $\begin{array}{l}\text { Classification of } \\
\text { Journal* }\end{array}$ & $\begin{array}{l}2010- \\
2015\end{array}$ & $\begin{array}{l}2016- \\
2020\end{array}$ & $\begin{array}{l}\text { Total number of } \\
\text { papers }\end{array}$ \\
\hline 1. Educational Technology \& Society & $\mathrm{T}$ & 4 & 13 & 17 \\
\hline $\begin{array}{l}\text { 2. Computer Assisted Language } \\
\text { Learning }\end{array}$ & $\mathrm{L}$ & 5 & 11 & 16 \\
\hline 3. Computers \& Education & $\mathrm{T}$ & 5 & 10 & 15 \\
\hline 4. Language Learning \& Technology & L & 1 & 13 & 14 \\
\hline 5. ReCALL & L & 4 & 7 & 11 \\
\hline $\begin{array}{l}\text { 6. Journal of Computer Assisted } \\
\text { Learning }\end{array}$ & $\mathrm{T}$ & 4 & 1 & 5 \\
\hline 7. Interactive Learning Environments & $\mathrm{T}$ & 1 & 4 & 5 \\
\hline $\begin{array}{l}\text { 8. British Journal of Educational } \\
\text { Technology }\end{array}$ & $\mathrm{T}$ & 1 & 3 & 4 \\
\hline $\begin{array}{l}\text { 9. Educational Technology Research and } \\
\text { Development }\end{array}$ & $\mathrm{T}$ & 1 & 2 & 3 \\
\hline 10. System & L & 0 & 3 & 3 \\
\hline
\end{tabular}

Джерело: author research.

\section{Methodology}

The methodology consisted of two elements of classification of scientific publications: types of interactive methods in teaching foreign languages and the effects of interactive methods in teaching. The first stage of the research was the selection of publications according to the research methodology: preference was given to publications with quantitative evaluation methods (questionnaires and statistical processing of questionnaires).

Figure 1. Five types of technologies for language learning

Gamified language learning

STR- and TSR-assisted language learning

Socialised language learning

Mulmedia language learning

Mobile-assisted language learning

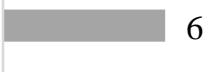

6

12

$\begin{array}{lllllll}0 & 5 & 10 & 15 & 20 & 25 & 30\end{array}$

Numbers of publications 
Source: author research.

As a result of the first stage we can see that 93 publications for 2010-2020 (Table 1) are devoted to interactive technologies of foreign language teaching in higher education institutions. $A$ selection of 76 articles concerning the research issues was formed. Filtering of publications was carried out taking into account the following criteria: publication citation index, research methodology (qualitative research was not taken into account), research sample (the sample must include articles where the integration of interactive technologies in higher education institutions is under study).

\section{RESULTS AND DISCUSSION}

\section{Historical trends in the usage of interactive methods of teaching foreign languages}

New technologies will expand the intercultural concept of learning for intercultural communication and learning foreign languages, which requires the adaptation of teachers. The new interactive learning environment will include "the use of digital materials that are easily edited and customizable, a virtual or mobile learning environment, the integration of knowledge with social networks that connect people to ideas, an effort to personalize instruction as much as possible, and a belief that knowledge is best understood as a creative process of co-constructed meaning within a community of practice." (Blyth, C., 2018).

Moreover, the role of a foreign language teacher is being transformed due to the greater amount of authentic content on the Internet. Teachers in the future will not provide "linguistic input and corrective feedback", but will act as a personal tutor in the learning experience of students. As a result, mentoring and tutoring in foreign language teaching will become more widespread. Despite this, "teachers will need to help learners reflect on their experiences and gain a greater awareness of contextual and cultural variables" (Haugh, M., 2017).

This pedagogical trend has accelerated in the last ten years. For example, in the 1980s, when applied linguists encourage using authentic materials to counter the artificiality of formal learning, teachers began to emphasize the importance of the cultural context. As a result, foreign language teachers have moved away from their traditional, didactic concept of foreign language teaching, based on formal, non-contextual rules, in favor of contextual tasks that were a priority for discussion.

Although communicative foreign language learning has undoubtedly helped teachers to overcome the artificiality of formal learning, the challenge remains to teach socially relevant knowledge of foreign language usage that is based on social and cultural factors and does not occur in the context of the audience. Therefore, the study of foreign languages and the development of intercultural communicative competence remain problematic, taking into account the lack of external practical foreign context 
The usage of technology for learning foreign languages is rapidly increasing. Smartphones and tablets are considered to be the most important devices in the classroom. Learning platforms and programs are developing rapidly, which ensures the growth of "practices of technologyenhanced language learning" (hereinafter, TELL) (Zhang, R., \& Zou, D., 2020).

Mobile learning refers to learning with mobile devices, such as smartphones, tablets, digital pens, and wearable devices like smartwatches, AR and VR glasses (Huang, C. S., Yang, S. J., Chiang, T. H., \& Su, A., 2016). Multimedia-assisted language learning refers to presenting language knowledge (e.g. grammar knowledge and word concept) or conducting learning activities (e.g. exercises and instructional games) using multimedia, such as videos, audios, and images (Aldera, A. S., \& Mohsen, M. A., 2013). Socialised learning refers to learning with socialisation tools such as online platforms or communities and social networks (Çetinkaya, L., \& Sutcu, S. S., 2018). Technologies for speech-to-text recognition and text-to-speech recognition (STR and TSR) refer to the technologies that automatically generate the textual or audio counterparts of learners' speech (or writing). The literature indicates that they are effective in deepening learners' knowledge processing and memorisation by strengthening the connections between audio and textual forms of language knowledge (Mayer, R. E., \& Moreno, R., 2003; Shadiev, R., Hwang, W. Y., \& Liu, T. Y., 2018). Game-based learning refers to the integration of game elements (e.g. rules and goals, challenge, mystery/storyline, rewards, etc.) in delivering instructional content and conducting learning activities (Yukselturk et al., 2018).

\section{Effectiveness and effects of implementing interactive methods of teaching foreign languages in higher education institutions}

Recent research focuses on the study of the effectiveness of technology in the educational process of universities, the study of English as a second language (Hwang, G. J., \& Fu, Q. K., 2018). The study of the peculiarities of teaching English as a foreign language is concerned in the works of Slavuj et al. (2017) and Shadiev, Hwang, et al. (2017), which studies the effectiveness, psychological features of usage "game genres, which were normally integrated into learning tasks, immersion games and multiplayer online role-playing games" in the teaching process. The research focuses on students of the universities with different level of foreign language proficiency. The positive influence of digital games as a method of teaching a foreign language is proved.

Most studies of interactive teaching methods are focused on one-session or short-term. The study of context-aware technology in foreign language teaching indicates the general positive effects of these technologies "on learners' affective, linguistic, socio-cultural, and cognitive states, while learners 'actual learning outcomes were seldom investigated" (Lee, S. M., 2019)

The study has shown that the study of interactive technologies in English language learning is complemented by the study of the effect of technology in Chinese language learning. There is students' vocabulary, writing skills, speaking skills among the subjects of research. The study has found the use of 23 types of technologies in foreign language teaching, "among which digital games, corpus, and automated feedback were used most frequently" (Shadiev, R., \& Yang, M., 2020). 


\section{Mobile-assisted language learning}

Mobile-assisted language learning generally provides positive effects (Figure 2). This method of teaching is used to study vocabulary, integrated learning, listening, speaking skills and reading in most cases. This method is least used for the development of writing, grammar skills and pronunciation. This indicates the peculiarities of foreign language teaching: as a rule, students spend a lot of time learning words, acquiring conversational skills, so interactive teaching methods are most suitable in these aspects.

The necessity for spoken communication in a multilingual environment has also led to a high level of usage of interactive methods. It is very important if a peson wants to acquire listening, reading and speaking skills. Acquiring writing skills is becoming a more difficult process due to the low prevalence of virtual keyboards on mobile devices.

Calculations show that $63 \%$ of studies found positive effects of Mobile-assisted language learning. Moreover, the greatest effect of this type of interactive methods of foreign language teaching is observed in word learning, integrated learning, reading and speaking (Figure 2).

Figure 2. Effects of Mobile-assisted language learning in higher education

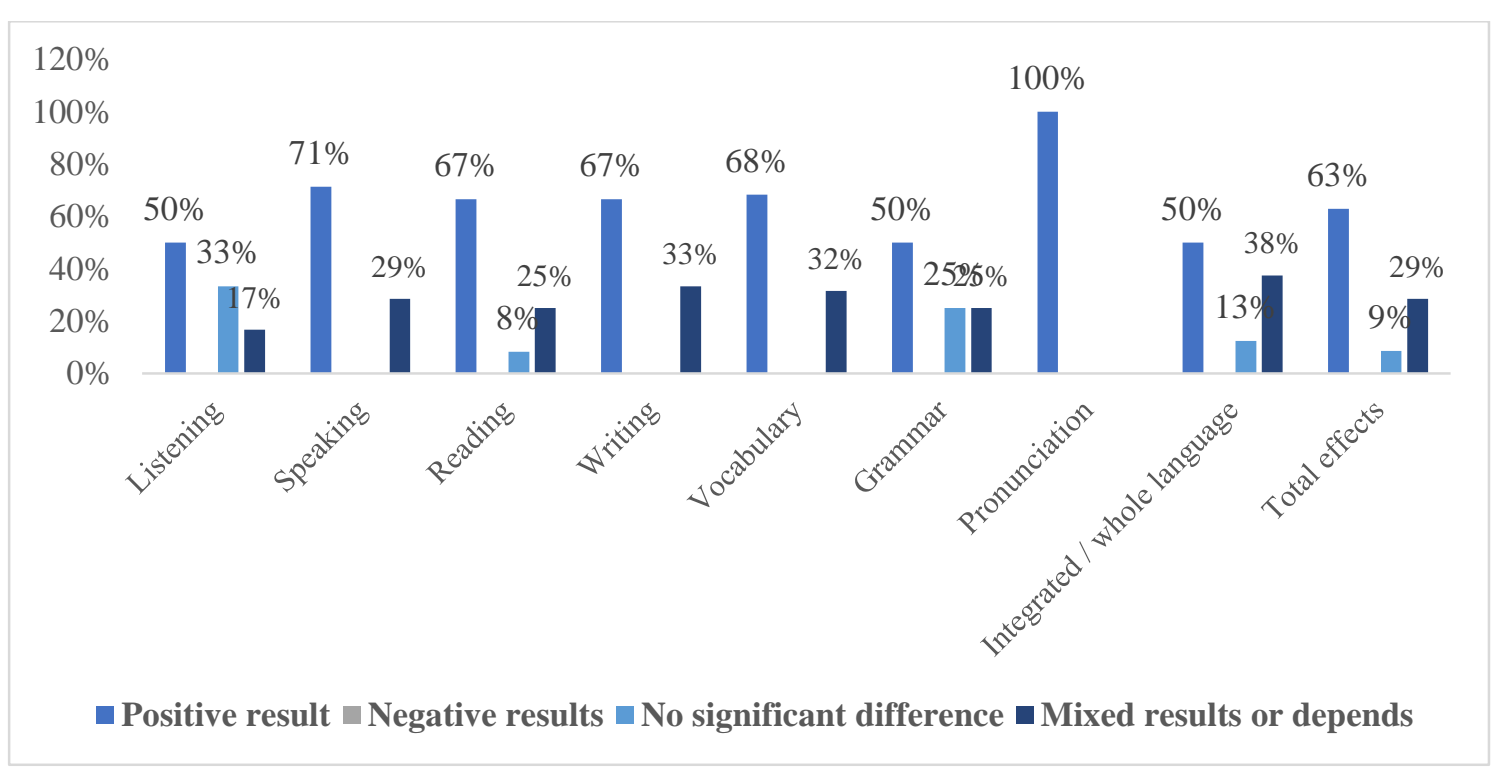

Source: author research.

$9 \%$ of research results have not revealed significant differences and $29 \%$ of studies have proven the lack of positive effects of Mobile-assisted language learning.

Further research should focus on further study of the factors that stimulate the effectiveness of Mobile-assisted language learning, learning conditions and strategies. While the effects are obvious for speaking skills, learning words, writing and pronunciation, the effects are difficult to detect for listening, reading and grammar skills. Adverse effects are associated with insufficient research in research. 


\section{Mulmedia language learning}

Moodle, an interactive multimedia learning software, is the most popular way to learn foreign languages. The effectiveness of Mulmedia language learning has been proven in a number of studies. In one study, the appropriate use of multimedia promoted learning by deepening knowledge processing and promoting motivation (Hwang, Shadiev, Hsu, Huang, Hsu, \& Lin, 2016). Okuno and Hardison (2016) have compared the effectiveness of the auditory-visual and auditory systems only in learning a foreign language pronunciation and have found that the combination of audio and video is the optimal tool for learning vowels.

Both Chen, Tan, and Lo (2016), and Liakin, Cardoso, and Liakina (2017) report some positive learning outcomes using Moodle - an interactive multimedia learning software. Some studies also suggest the integrated use of technologies for multimedia learning of foreign languages. For example, Liu, Chen, and Hwang (2018) have developed a collaborative e-learning system using video-based materials and tools for conscious foreign language learning. Participants trained in a fitness center and the level of their audio-skills and listening improved significantly.

\section{Socialised language learning}

Online platforms can support the learning process (e.g., discussion forums for sharing information) and provide students with learning content (e.g., Edpuzzle and Quizlet for language input), and social networks form online communities (e.g., WhatsApp and Facebook), \& Sutcu, SS, 2018). Both online platforms and social networks have become an integral part of modern life and are widely used in many universities for teaching foreign languages (Liu, Tai, \& Liu, 2018).

Lin and Hwang (2018) has investigated the usage of Facebook in online audiences when learning foreign languages and has found it very effective in improving students' oral skills and enhancing their interactive behavior among peers both inside and outside the application. Yang (2016) developed an online learning platform ESP Cafe, where a discussion forum was one of the main components of foreign language learning.

\section{STR- and TSR-assisted language learning}

Shadiev, Hwang, and Liu (2018) integrated both STR and TSR into a smart-watch learning system. During the learning of language skills with the help of STR, students' mistakes were recognized and text was generated to correct them. TSR was used in writing exercises to help students avoid grammatical and spelling mistakes by offering automatic correct versions. The results have shown that participants who were taught foreign languages with the help of STR and TSR had very effective learning outcomes and a positive perception of the learning system.

Bodnar, Cucchiarini, Penning de Vries, Strik, and van Hout (2017) have developed a corrective feedback system (CF) that helps oral grammar learning by automatically recognizing and pointing out mistakes in students' speech. Despite the fact that the results have not shown a significant impact of the CF system, there was a significant potential of automatic speech recognition technology in the study of oral grammar. Nguyen, Hwang, Pham and Ma (2018) have integrated STR technology with cloud translation technology and developed a mobile application 
called ezTranslate that automatically recognizes and translates student language and allows students to repeat after pronunciation. The results have shown that students' general language skills were improved after using ezTranslate.

\section{Gamified language learning}

Language courses that use a play environment have helped to engage students, enhance their interaction and improve their knowledge of a foreign language (Hwang, W. Y., et al., 2018). There are some works that are important in this field of study and among the peer-reviewed studies. Rachels and Rockinson-Szapkiw (2018) have developed a Spanish game-based course to enhance the general language skills of beginners. The games were based on the free DuolingoVR application, which can personalize the learning experience by providing students with appropriate scaffolding and adapting instruction to suit their level of language proficiency. Similarly, Hung (2017) has gamified classroom learning using Kahoot !, another free app that can be used to create learning games.

Some game-based language learning studies have integrated other technologies, such as Kinect technology and augmented reality (AR). For example, Yukselturk and others (2018) have developed three games that immersed students in a play environment where they took an active role in learning by interacting with others. Kinect technology was used to improve students' play experience. To adopt synchronous commands based on students' responses, they used a motion sensor - input device consisting of an RGB camera, three-dimensional depth sensors, a multimassive microphone, and built-in processing cores.

It was found that the players of the game have achieved significant development in speech, listening, reading and writing. Hsu (2017) has also developed a task-based game system to facilitate vocabulary learning. The enhanced AR game created a three-dimensional space where students gained and applied language skills in virtual and real dimensions. The results have shown that students who studied with AR achieved better learning outcomes than those who did not.

\section{CONCLUSION}

Interactive teaching methods have become an integral part of foreign language teaching. The research has proved the effectiveness of learning using technology. However, not all studies prove the effectiveness of interactive teaching methods. Difficulties in identifying the effect arise due to the inability to assess foreign language skills.

The research has shown that the positive effects of interactive methods may disappear over time when students lose interest in a new interactive technology that becomes a learning tool. To solve this problem, teachers can use different ways of innovative strategies and teaching skills. They can integrate them into learning using technology.

Many studies have proven the positive effects of interactive technologies or new ways of interacting in the process of foreign language learning. They help improve foreign language skills and student achievement. For example, the effectiveness of real-time learning technology and 
teaching classmates in online classrooms, the introduction of game learning has been proven. Different approaches to the usage of interactive teaching methods and strategies are needed to maintain a certain level of student motivation and involvement in the learning process. Knowledge of students' foreign language determines their level of benefit in the future profession.

\section{REFERENCES}

Aldera, A. S., \& Mohsen, M. A. (2013). Annotations in captioned animation: Effects on vocabulary learning and listening skills. Computers \& Education, 68, 60-75.

Arrosagaray, M., González-Peiteado, M., Pino-Juste, M., Rodríguez-López, B. (2019). A comparative study of Spanish adult students' attitudes to ICT in classroom, blended and distance language learning modes, Computers \& Education, 134, 31-40, ISSN 0360-1315, https://doi.org/10.1016/i.compedu.2019.01.016

Benta, D., Bologa, G., Dzitac I. (2015). University Level Learning and Teaching via E-Learning Platforms, Procedia Computer Science, 55, 1366-1373, ISSN 1877-0509, https://doi.org/10.1016/i.procs.2015.07.123.

Blyth, C. (2012). Opening up FL education with open educational resources: The case of Français interactif. In F. Rubio \& J. Thoms (Eds.), Hybrid language teaching and learning: Exploring theoretical, pedagogical and curricular issues (pp. 196-218). Boston: Heinle Thomson.

Blyth, C. (2018). Immersive technologies and language learning. Foreign Language Annals, 51(1), 225-232.

Bodnar, S., Cucchiarini, C., Penning de Vries, B., Strik, H., \& van Hout, R. (2017). Learner affect in computerised L2 oral grammar practice with corrective feedback. Computer Assisted Language Learning, 30(34), 223-246. doi:10.1080/09588221.2017. 1302964

Boa Sorte, P. (2020). Mark the correct answer? To whom? Deconstructing reading comprehension. Journal of Research and Knowledge Spreading, 1(1), 1-8.

Byram, M. (1997). Teaching and assessing intercultural communicative competence. Clevedon, UK: Multilingual Matters.

Çetinkaya, L., \& Sutcu, S. S. (2018). The effects of Facebook and WhatsApp on success in English vocabulary instruction. Journal of Computer Assisted Learning, 34(5), 504-514. doi:10.1111/jcal.12255

Chen, C. M., Tan, C. C., \& Lo, B. J. (2016). Facilitating English-language learners' oral reading fluency with digital pen technology. Interactive Learning Environments, 24(1), 96-118. doi:10.1080/10494820.2013.817442

Dashti, E. (2020). Examining the relationship between unwillingness to translate and personality type of Iranian translation students. Journal of Research and Knowledge Spreading, 2020, 1(1), 1-10.

Drake, B. M.,Walz, A. (2018). Evolving Business Intelligence and Data Analytics in Higher Education. New Directions for Institutional Research, 39-52. doi:10.1002/ir.20266

Ebrahimi, M. A. (2020). Cultural value of translation of proverbs and synopsis. Journal of Research and Knowledge Spreading, 1(1), 1-10.

Fullagar, S. (2019). A physical cultural studies perspective on physical (in)activity and health inequalities: the biopolitics of body practices and embodied movement. Revista Tempos e Espaços em Educação, 12(28), 63-76. 
Georgieva-Tsaneva, G., Bogdanova, G., Negoslav Subev, N. (2017). Characteristics of Interactivity and Using the Interactive Technologies in System North+. Digital Presentation and Preservation of Cultural and Scientific Heritage. Conference Proceedings. Vol. 7, Sofia, Bulgaria: Institute of Mathematics and Informatics - BAS, 133-142.

Haugh, M. (2017). Translation technology is useful but should not replace learning languages. The Conversation. Retrieved from https://theconversation.com/translation-technology-is-usefulbut-should-notreplace-learning-languages-85384

Hsu, T. C. (2017). Learning English with augmented reality: Do learning styles matter? Computers \& Education, 106, 137-157. doi:10.1016/j.compedu.2016.12.007

Huang, C. S., Yang, S. J., Chiang, T. H., \& Su, A. (2016). Effects of situated mobile learning approach on learning motivation and performance of EFL students. Journal of Educational Technology \& Society, 19(1), 263-276.

Hung, H. T. (2017). Clickers in the flipped classroom: Bring your own device (BYOD) to promote student learning. Interactive Learning Environments, 25(8), 983-995. doi: $10.1080 / 10494820.2016 .1240090$

Hwang, G. J., \& Fu, Q. K. (2018). Trends in the research design and application of mobile language learning: A review of 2007-2016 publications in selected SSCI journals. Interactive Learning Environments, $27(4), 567-581$.

Hwang, W. Y., Shadiev, R., Hsu, J. L., Huang, Y. M., Hsu, G. L., \& Lin, Y. C. (2016). Effects of storytelling to facilitate EFL speaking using Web-based multimedia system. Computer Assisted Language Learning, 29(2), 215-241. doi:10.1080/09588221.2014. 927367

Institute for the Future. (2017). Future work skills 2020 report. Retrieved from https://www.iftf.org/futureworkskills/

Keane, T., Keane, W. F., Blicblau, A. S. (2016). Beyond traditional literacy: Learning and transformative practices using ICT. Education and Information Technologies, 21(4), 769-781. doi: https://dx.doi.org.ezproxy.uned.es/10.1007/s10639-014-9353-5

Kebble, P.G. (2017). Assessing Online Asynchronous Communication Strategies Designed to Enhance Large Student Cohort Engagement and Foster a Community of Learning. Journal of Education and Training Studies, 5(8), 92-100. doi: https://doi.org/10.11114/iets.v5i8.2539

Lee, S. M. (2019). A systematic review of context-aware technology use in foreign language learning. Computer Assisted Language Learning. doi:10.1080/09588221.2019. 1688836

Liakin, D., Cardoso, W., \& Liakina, N. (2017). The pedagogical use of mobile speech synthesis (TTS): Focus on French liaison. Computer Assisted Language Learning, 30(3-4), 325-342.

Lin, C. J., \& Hwang, G. J. (2018). A learning analytics approach to investigating factors affecting EFL students' oral performance in a flipped classroom. Journal of Educational Technology \& Society, 21(2), 205-219.

Liu, G. Z., Chen, J. Y., \& Hwang, G. J. (2018). Mobile-based collaborative learning in the fitness center: A case study on the development of English listening comprehension with a context-aware application. British Journal of Educational Technology, 57(2), 305-320. doi:10.1111/bjet.12581

Liu, K. P., Tai, S. J. D., \& Liu, C. C. (2018). Enhancing language learning through creation: The effect of digital storytelling on student learning motivation and performance in a school English course. 
Educational Technology Research and Development, 66(4), 913-935. doi:10.1007/s11423-0189592-z

Mayer, R. E., \& Moreno, R. (2003). Nine ways to reduce cognitive load in multimedia learning. Educational Psychologist, 38(1), 43-52.

Moreno, V., Cavazotte F., Cavazotte, F., Alves I. (2016). Explaining university students' effective use of elearning platforms: Effective use of e-learning platforms. British Journal of Educational Technology, 48(4), DOI: 10.1111/bjet.12469

Nguyen, T. H., Hwang, W. Y., Pham, X. L., \& Ma, Z. H. (2018). User-Oriented EFL Speaking through Application and Exercise: Instant Speech Translation and Shadowing in Authentic Context. Journal of Educational Technology \& Society, 21(4), 129-142.

Okuno, T., \& Hardison, D. M. (2016). Perception-production link in L2 Japanese vowel duration: Training with technology. Language Learning \& Technology, 20(2), 61-80.

Pokrivcakova, S. (2019). Preparing teachers for the application of Al-powered technologies in foreign language education. Journal of Language and Cultural Education, 7(3), 135-153.

Rachels, J. R., \& Rockinson-Szapkiw, A. J. (2018). The effects of a mobile gamification app on elementary students' Spanish achievement and self-efficacy. Computer Assisted Language Learning, 31(1-2), 72-89. doi:10.1080/09588221.2017.1382536

Rolim, C. and Isaias, P. (2019). Examining the use of e-assessment in higher education: teachers and students' viewpoints. British Journal of Educational Technology, 50, 1785-1800. doi:10.1111/bjet.12669

Serrano, D. R., Dea-Ayuela, M. A., Gonzalez-Burgos, E., Serrano-Gil, A., Lalatsa, A. (2019). Technologyenhanced learning in higher education: How to enhance student engagement through blended learning. European Journal of Education, 54, 273- 286. https://doi.org/10.1111/ejed.12330

Shadiev, R., \& Yang, M. (2020). Review of studies on technology-enhanced language learning and teaching. Sustainability, 12(2), 524.

Shadiev, R., Hwang, W. Y., \& Huang, Y. M. (2017). Review of research on mobile language learning in authentic environments. Computer Assisted Language Learning, 30(3-4), 284-303.

Shadiev, R., Hwang, W. Y., \& Liu, T. Y. (2018). A Study of the Use of Wearable Devices for Healthy and Enjoyable English as a Foreign Language Learning in Authentic Contexts. Journal of Educational Technology \& Society, 21(4), 217-231.

Slavuj, V., Mestrovic, A., \& Kovacic, B. (2017). Adaptivity in educational systems for language learning: A review. Computer Assisted Language Learning, 30(1-2), 64-90.

Stewart, C., Wolodko, B. (2016). University Educator Mindsets: How Might Adult ConstructiveDevelopmental Theory Support Design of Adaptive Learning?. Mind, Brain, and Education, 10, 247-255. doi: $10.1111 / \mathrm{mbe} .12126$

Trigueros Rueda, Y. (2017). The influence of new technologies in foreign language learning. https://addi.ehu.es/bitstream/handle/10810/21431/GRAL TriguerosRueda\%2cY.pdf?sequence $=1 \&$ is Allowed $=y$

Viktorov, L. V., Kocharyan, A. B., \& Korotun, O. O. (2018). Information and communication technologies in foreign language education for the third age learners. Інформаційні технології і засоби навчання, (63,№ 1), 22-35. 
Yang, Y. F. (2016). Self-directed learning to develop autonomy in an online ESP community. Interactive Learning Environments, 24(7), 1629-1646. doi:10.1080/10494820. 2015.1041402

Yukselturk, E., Altıok, S., \& Bas, er, Z. (2018). Using Game-Based Learning with Kinect Technology in Foreign Language Education Course. Journal of Educational Technology \& Society, 21(3), 159-173.

Zekiye, Ö. Z. E. R. (2018). An investigation of prospective ELT teachers' attitudes towards using computer technologies in foreign language teaching. Dil ve Dilbilimi Çalışmaları Dergisi, 14(1), 328-341.

Zhang, R., \& Zou, D. (2020). Types, purposes, and effectiveness of state-of-the-art technologies for second and foreign language learning. Computer Assisted Language Learning, 1-47.

Zhu, E. (2017). Breaking Down Barriers to the Use of Technology for Teaching in Higher Education. To Improve the Academy, 26, 305-318. doi:10.1002/j.2334-4822.2008.tb00516.x

\section{$\underline{\text { ABOUT THE AUTHORS }}$}

\section{Oleksiienko A. Larysa}

Candidate of Pedagogical Sciences, Associate Professor, Department of International Economic Relations, Administration and Language Training, Affiliate "Kremenchuk Institute of Higher Educational Establishment "Alfred Nobel University". Dnipro, Dnipropetrovsk Oblast, Ukraine.

E-mail: npu.institute@gmail.com

ORCID: https://orcid.org/0000-0002-3509-388X

\section{Trubitsyna M. Olga}

Candidate of Pedagogical Sciences, Associate Professor, South-Ukrainian National Pedagogical University named after K. D. Ushynsky, Faculty of foreign languages, Department of the Germanic Philology and Methods of Teaching Foreign Languages. Odesa, Odessa Oblast, Ukraine.

E-mail: t21535673@gmail.com

ORCID: https://orcid.org/0000-0001-78302576

\section{Balanaieva V. Oksana}

PhD, Head of the Department of Foreign Languages, Donetsk Law Institute of the Ministry of Internal Affairs of Ukraine, Department of Foreign Languages. Kryvyi Rih, Dnipropetrovsk Oblast, Ukraine.

E-mail: oksana5556.oks@gmail.com

ORCID: https://orcid.org/0000-0003-0102-0911

\section{Mamonova I. Olena}

PhD, Assistant professor of the Department of Humanitarian Disciplines, Donetsk Law Institute of the Ministry of Internal Affairs of Ukraine, Department of Humanitarian Disciplines. Kryvyi Rih, Dnipropetrovsk Oblast, Ukraine.

E-mail: phd.lin.lin12@gmail.com

ORCID: https://orcid.org/0000-0001-9648-1627

\section{Polytsia D. Tetiana}

Ph.D. in Philological Sciences, Associate Professor of The Department of Ukrainian Studies, National Pirogov Memorial Medical University. Vinnytsia, Vinnytsia Oblast, Ukraine.

Email: 14tetiankapolucia@gmail.com

ORCID: https://orcid.org/0000-0002-0390-940X 
Received on: 08-11-2020

Approved on: 11-23-2020

Published on: 12-13-2020 